\title{
Luzula spicata (Juncaceae) in the Ukrainian Carpathians: on the brink of extinction
}

\author{
Yuriy KOBIV \\ Institute of Ecology of the Carpathians, National Academy of Sciences of Ukraine \\ 4, Kozelnytska Str., Lviv 79026, Ukraine \\ Botanical Garden of Ivan Franko National University of Lviv \\ 44, Cheremshyny Str., Lviv 79014, Ukraine \\ ykobiv@gmail.com
}

Kobiv Y. Luzula spicata (Juncaceae) in the Ukrainian Carpathians: on the brink of extinction. Ukr. Bot. J., 2018, 75(1): 70-76.

Abstract. Historical records on distribution of Luzula spicata in the Ukrainian Carpathians from past publications and herbarium specimens were analyzed. This arctic-alpine species formerly occurred at the uppermost elevations in three mountain massifs: the Chornohora, Marmarosh and Chyvchyny Mts. It was confined to acidic sandstone and conglomerate rocks on mountain summits and ridges with the lowest thermal conditions. Thorough recent surveys of all the eight previously documented localities allowed to reconfirm the occurrence of L. spicata in one station only, namely near the summit of Mt. Pip Ivan (1990 m a.s.l.) in the Chornohora Mts where its small population has survived. Apparently, the species has become extirpated elsewhere in the Ukrainian Carpathians. A map of current and extinct localities is provided, as well as an image of the recent herbarium specimen. Luzula spicata is one of the most cryophilic species of the Carpathian flora and its Ukrainian localities refer to the lower limit of the species altitudinal range. Therefore, its decline and extinction can be attributed to climate change that has also been reported from other mountain systems of Europe. Analysis of past data showed that most probably the species has already been gradually dying off since the end of the so-called "Little Ice Age" (i.e. 100-150 years ago) that was followed by progressive warming. Luzula spicata is a poorly competitive species confined to rocky habitats with scarce vegetation cover. It is vulnerable both to the direct impact of warming and to replacement by taller graminoids or dwarf shrubs encroaching on the alpine habitats in the course of the climate-induced succession. Because L. spicata is on the brink of extinction, it should be included in the next edition of the Red Data Book of Ukraine as Critically Endangered (CR).

Keywords: cryophilic species, climate change, locality, extinction, Carpathians

\section{Introduction}

Assessment of current conservation status of rare and endangered species, as well as determining the level of threat to them require repeated surveys of their known localities, which enable to reveal dynamic trends in their populations. However, many plant species listed in the Red Data Book of Ukraine (Chervona knyha Ukrainy..., 2009) lack such comprehensive data, which also refers to other rare species. That fully concerns the Carpathian region where inventories are most hard to perform because of poor accessibility of some highmountain areas.

This article is supposed to fill that gap with regard to one oreophytic species - Luzula spicata (L.) DC. The aim of the study was to check the known localities of the species and to define its current status. Another goal was to find out whether the species still occurs in the

(C) Yu. KOBIV, 2018
Ukrainian Carpathians because reasonable doubts in its survival have been expressed (Olshanskyi, 2014; Kobiv et al., 2017).

Luzula spicata is an arctic-alpine species spread in the north of America and Europe, as well as in the temperate zone at upper elevations in the mountains of North America, Eurasia and North Africa (Atlas Mts).

The species is rather polymorphic and its several subspecies have been defined in Europe (Kirschner, 2002). In the Carpathians, it is represented by L. spicata subsp. conglomerata (W.D.J. Koch) Murr (= L. spicata subsp. mutabilis Chrtek \& Křisa), a subspecies with disjunct distribution, which also occurs in the Pyrenees, Alps, Swiss Jura and Northern Apennines (Chrtek, Křisa, 1962, 1980; Kirschner, 2002).

In the Carpathians, L. spicata is the only representative of the section Alpinae (Chrtek, Krrisa, 1962, 1980; Kirschner, 2002) and is well-distinguishable for its 


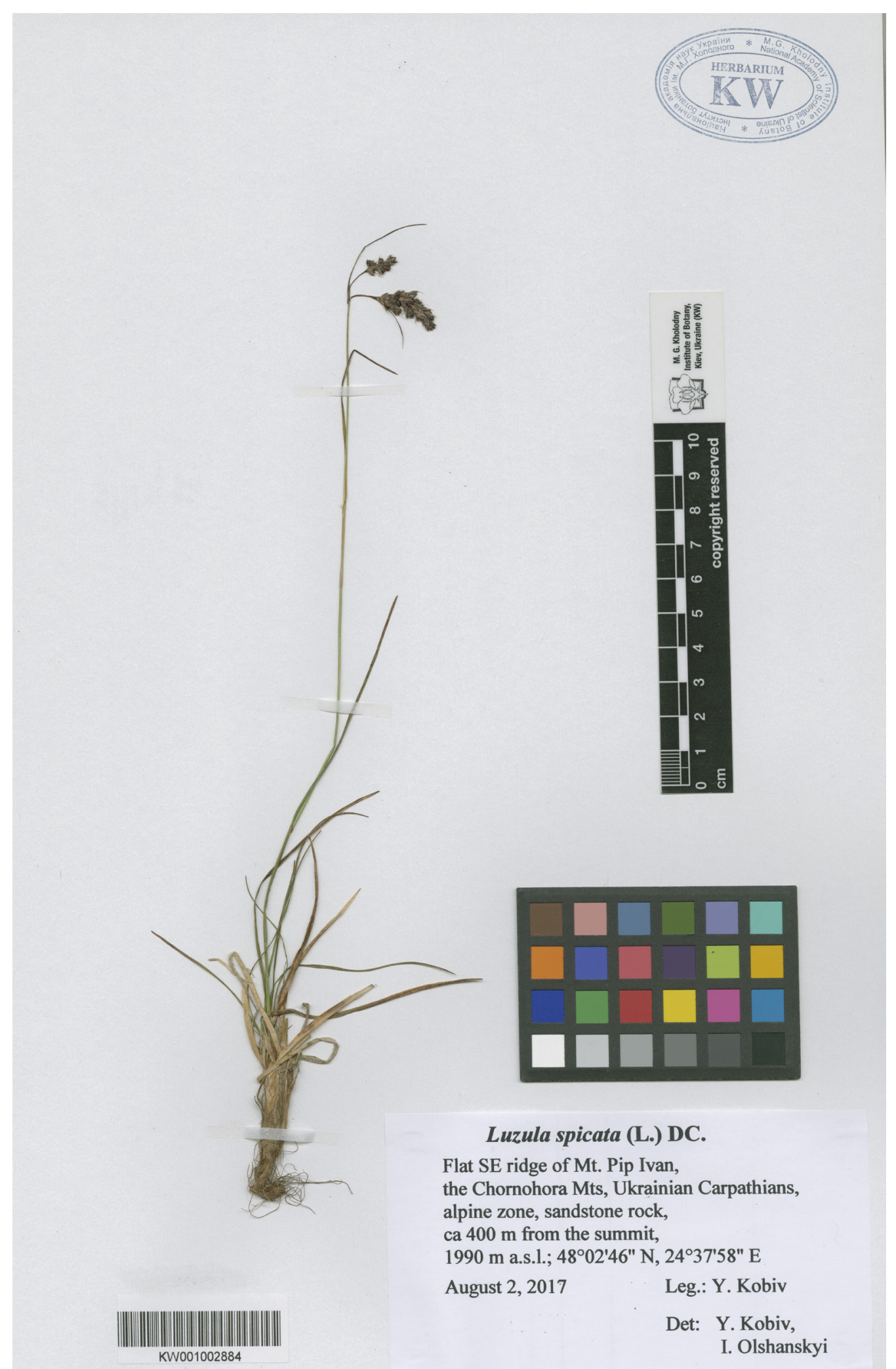

Fig. 1. A recent herbarium specimen of Luzula spicata from Mt. Pip Ivan in the Chornohora Mts 
spike-like nodding inflorescence (Fig. 1) differing from other native species of Luzula DC.

\section{Materials and methods}

Past publications and available herbarium data on Luzula spicata in the Ukrainian Carpathians have been analyzed. In total, I found 10 corresponding herbarium sheets: 9 - in Polish herbaria of Cracow (KRAM, KRA), and 1 - in Lviv (LWS).

Historical records were checked in the Chornohora (in 2015, 2016, and 2017), Marmarosh (2016) and Chyvchyny Mts (2012) during field research. Suitable rocky and low-sward alpine habitats were thoroughly surveyed in search of the species in its previously documented localities and their vicinity.

The collected specimen (Fig. 1) is deposited at the Herbarium of the M.G. Kholodny Institute of Botany, Kyiv $(K W)$.

\section{Results and discussion}

Previous data on distribution in Ukraine. Luzula spicata is mentioned in the main floristic compendia regarding the Ukrainian Carpathians (Krechetovych, Barbarych, 1950; Chopyk, 1976; Vyznachnyk roslyn..., 1977).

However, information on the species occurrence is based merely on original historical data from the second half of the $19^{\text {th }}$ - first half of the $20^{\text {th }}$ century. The first author to record L. spicata in the part of the Carpathians, which now belongs to Ukraine, was Rehman (1873) who reported it from several highest summits of the Chornohora ridge - Mts Hoverla, Rebra, Brebeneskul and Pip Ivan.

Zapałowicz (1889), who performed the most comprehensive floristic inventory of the Chornohora in the 1880s, reconfirmed the species occurrence on Mts Pip Ivan and Rebra and documented its exact location.

Localities of L. spicata in the Chornohora Mts were also proved by herbarium specimens gathered in the 1930s by Mądalski at high altitudes ( $\geq 1910 \mathrm{~m}$ a.s.1.) on Mts Pip Ivan, Gutyn-Tomnatyk and Turkul. The herbarium labels indicate the location of these stations quite explicitly.

In addition, the species was reported by Zapałowicz (1889) from the Marmarosh range, namely from Mt. Pip Ivan Marmaroskyi. Its elevation (1940 m a.s.1.) corresponds to the very top of the mountain.

Another series of the species records refers to the summit of Mt. Hnetiesa in the Chyvchyny Mts, where it was discovered by Wołoszczak (1888) in the late $19^{\text {th }}$ century. That locality was reconfirmed later by a number of herbarium specimens gathered mostly in the 1930s. Moreover, in Pawłowski and Walas' (1949) publication on the vegetation of the Chyvchyny Mts L. spicata is listed in the phytosociological relevé of the community Cetrario-Festucetum airoidis (alliance Juncion trifidi) from the saxicolous locality. Comments in the above publications and on the herbarium labels show that all this set of data refers to the conglomerate rock at the Ukrainian-Romanian border on the very top of Mt. Hnetiesa at 1760-1765 m a.s.1.

Thus, there are reliable historical data on the past occurrence of $L$. spicata in three mountain ranges of the Ukrainian Carpathians: the Chornohora, Marmarosh and Chyvchyny Mts (Fig. 2). While in the former two ranges the species is known from the high elevations in the alpine zone (> $1900 \mathrm{~m}$ a.s.l.), its locality in the Chyvchyny Mts can be regarded as subalpine.

Luzula spicata was also erroneously mentioned for the town of Chernivtsi by Tkachyk (2000), which resulted from misidentification of the herbarium specimen.

Ecological requirements. According to European compendia on ecological values of plants (Landolt, 1977; Ellenberg et al., 1992; Zarzycki et al., 2002), L. spicata is a highly specialized oreophyte and can be regarded as one of the most cryophilic species of the Carpathian flora. In the Carpathians, its ecological optimum and distribution range correspond to conditions of the subnival and upper alpine zones (Mirek, 1989).

Dahl (1998) stated that the main factor that determines the lower or southernmost limits of distribution of many cryophilic species is maximum summer temperature. He claimed that critical maximum summer temperature for L. spicata is $+24^{\circ} \mathrm{C}$, therefore climate warming should lead to the decline on the trailing (i.e. lower) edge of its distribution.

All the mentioned localities of $L$. spicata in the Ukrainian Carpathians have been reported from the uppermost parts of the mountains, i.e. their summits or ridges where the temperature is the lowest. The fact that most of the species localities have been documented in the Chornohora can be explained by the highest elevation of that range and, consequently, the lowest thermal conditions, which are crucial for that cryophilic species. However, these sparse suitable sites that comply with ecological requirements of $L$. spicata referred to the lowermost limits of the species altitudinal range as follows from its distribution in the Alps (Pauli et al., 2007; Frei et al., 2010) and Western Carpathians (Mirek, 1989). Therefore, climate warming, which has 


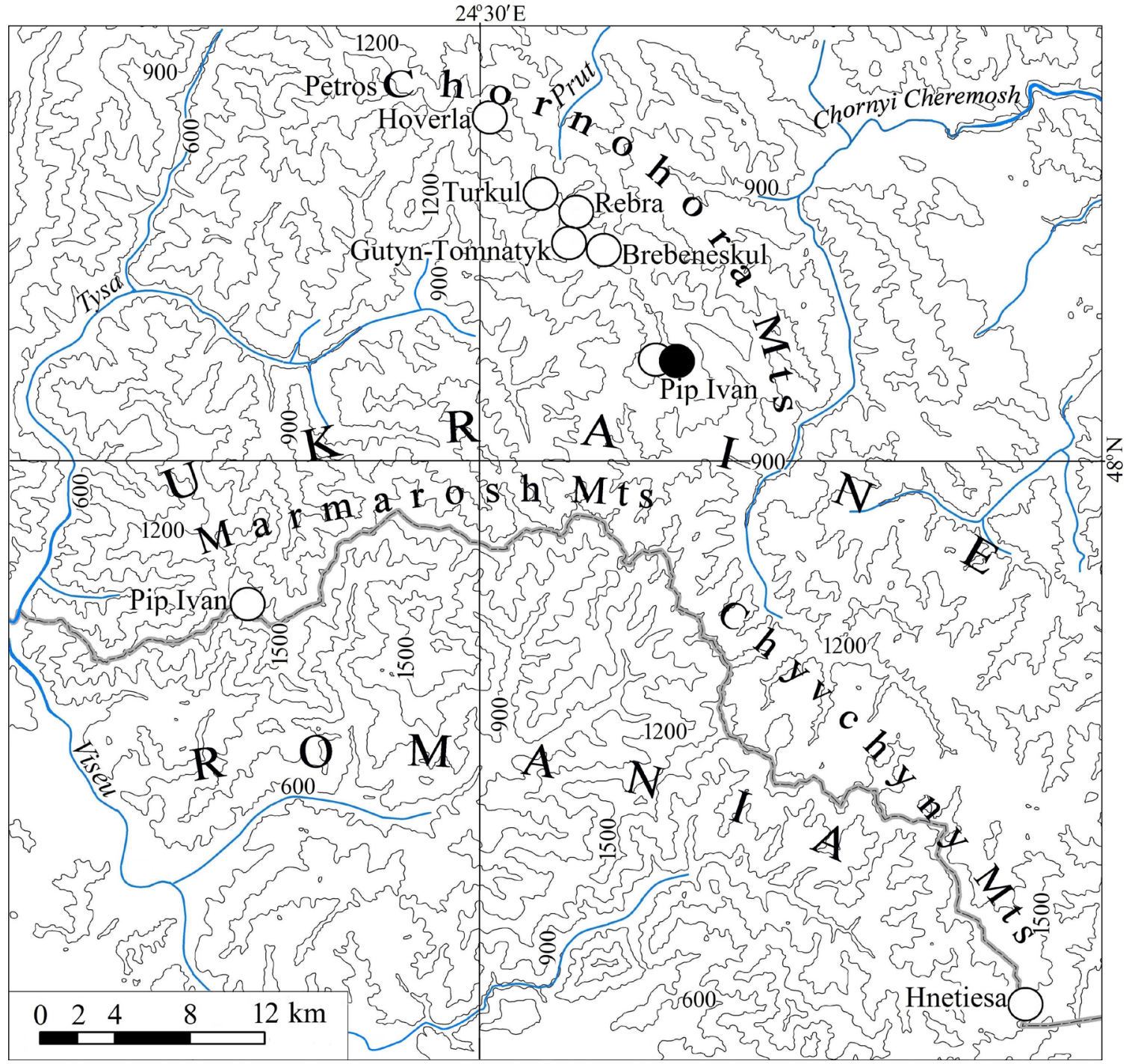

Fig. 2. Distribution of Luzula spicata in the Ukrainian Carpathians: • - current locality; $\bigcirc-$ extinct localities

been confirmed for the Carpathians lately (Spinoni et al., 2015) should have been causing the decline and extinction of that cryophilic species that has no available habitats to colonize.

The above-mentioned past publications and herbarium labels show that $L$. spicata in the Ukrainian Carpathians is a saxicolous species confined to sandstone and conglomerate rocks. It is defined as a characteristic species for the acidophilic syntaxonomic order Caricetalia curvulae and alliance Juncion trifidi (Matuszkiewicz, 2002). As follows from phytosociological prodromes of some Carpathian countries (Moravec, 1995; Matuszkiewicz, 2002), Luzula spicata is often associated with other markedly cryophilic alpine species - Agrostis rupestris All. and Oreochloa disticha (Wulfen) Link, whose negative dynamics was reported recently (Kyyak, 2013; Kobiv, 2017) and can also be explained by the adverse impact of climate change.

Current status and conservation implications. All the eight previously documented localities of Luzula spicata - 6 in the Chornohora, 1 - in the Marmarosh and $1-$ in the Chyvchyny Mts (Fig. 2) were checked during the surveys. However, despite the thorough search in these and nearby suitable habitats, I managed to find the species in one locality only. It is situated in the alpine zone on the flat south-eastern ridge of Mt. Pip Ivan in the Chornohora Mts at $1990 \mathrm{~m}$ a.s.1. $\left(48^{\circ} 02^{\prime} 46^{\prime \prime} \mathrm{N}\right.$, 
$24^{\circ} 37^{\prime} 58^{\prime \prime} \mathrm{E}$ ) about $400 \mathrm{~m}$ from the summit. The species occurs on the southern aspect of a sandstone rock on about $10 \mathrm{~m}^{2}$. The population is low-numbered and included only 6 flowering individuals in August 2017. The largest tufts cover up to $15 \mathrm{~cm}^{2}$. The number of vegetative individuals could hardly be estimated because they can be confused with those of the other graminoids. Vegetation cover at the site amounts to $25 \%$ and is formed by the following species with corresponding grades of the Braun-Blanquet scale: Luzula spicata - +, Festuca airoides Lam. - 2, Juncus trifidus L. - 1, Carex atrata L. - +, Hieracium alpinum L. - +, Campanula kladniana (Schur) Witasek -+ , Racomitrium canescens (Hedw.) Brid.) - 2, Tortella tortuosa (Hedw.) Limpr. - 1 . The size of that population of L. spicata is critically small and does not ensure its further survival even in the mid-term perspective. Apparently, the population is merely a remnant of formerly much larger entity, which once inhabited several ridges at the summit of Mt. Pip Ivan above $1980 \mathrm{~m}$ a.s.l. as follows from Zapałowicz's (1889) records and herbarium labels (KRAM 2745, 6209, 80235). These numerous historical data imply that this population could be the largest in the Ukrainian Carpathians in the past, which enabled it to survive until now.

Thus, the surveys carried out in the previously known localities showed that most probably $L$. spicata has declined significantly in its remaining locality on Mt. Pip Ivan in the Chornohora Mts and died out elsewhere in the Ukrainian Carpathians due to unfavorable climate warming impact, while thermal conditions in its scarce habitats got beyond the ecological range of that cryophylic species. The species is on the brink of extinction in Ukraine and its long-term survival in the region is problematic.

Luzula spicata is a poorly competitive saxicolous species confined to rocky habitats with scarce vegetation cover. It is vulnerable to replacement by taller graminoids or dwarf shrubs ingressing into the alpine habitats in the course of the climate-induced succession.

It is remarkable, that the old authors who surveyed the Carpathians in the $19^{\text {th }}$ century found the localities of $L$. spicata more often than their successors. For instance, Rehman (1873) after his rather brief investigation of the Chornohora Mts managed to report it from as much as four summits (see above). In addition, Deyl (1940), who performed the most comprehensive survey of the flora of Mt. Pip Ivan Marmaroskyi in the 1930s, did not mention L. spicata, though he could hardly miss it making a set of relevés on the top of that mountain where it had occurred in the late $19^{\text {th }}$ century (Zapałowicz, 1889).
Such a decreasing trend in the species findings could indicate that it has already been gradually dying off since the end of the so-called "Little Ice Age" (i.e. 100150 years ago) that was followed by progressive warming (Free, Robock, 1990). The lack of the species records in the Ukrainian Carpathians since World War II shows that most possibly it has become extremely rare in the region by the second half of the XX century.

Upward shifts in the species distribution and decline at its lower limit have been documented in the Alps recently (Pauli et al., 2007; Frei et al. 2010).

In the Ukrainian Carpathians, L. spicata is not only ecologically marginal (i.e. restricted to atypically low elevations), but also geographically peripheral, because it occurs at the north-eastern limit of the species distribution in Central Europe (Kobiv, 2017). Its closest to Ukraine localities are situated ca. $30 \mathrm{~km}$ westwards from the state border, in the Rodna Mts, Romanian Carpathians (Grințescu, 1966). Therefore, partial or total extinction of $L$. spicata, as well as other colddemanding alpine species (Agrostis rupestris, Saxifraga oppositifolia L., S. pedemontana All.) in the Ukrainian Carpathians leads to considerable contraction of their geographical ranges (Kobiv, 2017). This proves that climate change is a significant factor of biodiversity loss in the European scale, which particularly concerns alpine ecosystems.

Luzula spicata is on the Red List of the Czech Republic as "Critically Endangered" (Grulich, 2012), because it has been declining in the Sudeten Mts where it occurs at comparatively low elevation, apparently at the limit of its altitudinal range.

The species should be included in the next edition of the Red Data Book of Ukraine as Critically Endangered (CR) because it is threatened by extinction already in the mid-term perspective.

\section{Acknowledgements}

The author is grateful to Prof. Illya Chorney (Yuriy Fedkovych National University of Chernivtsi) for helpful remarks and to Dr. Igor Olshanskyi (M.G. Kholodny Institute of Botany, National Academy of Sciences of Ukraine, Kyiv) for useful advice and confirming the identification of the collected specimen of Luzula spicata.

This publication was prepared with support of the Ministry of Education and Science of Ukraine (grant 0116U001546) and the State Fund for Fundamental Research (grant F76/812017). 


\section{REFERENCES}

Chervona knyha Ukrainy. Roslynnyi svit (Red Data Book of Ukraine. Plant Kingdom). Ed. Ya.P. Didukh. Kyiv: Globalkonsaltyng, 2009, 912 pp. [Червона книга України. Рослинний світ. Ред. Я.П. Дідух. Київ: Глобалконсалтинг, 2009, 912 с.].

Chopyk V.I. Vysokohirna flora Ukrainskykh Karpat. Kyiv: Naukova Dumka, 1976, 270 pp. [Чопик B.I. Високогірна флора Українських Карпат. Київ: Наук. думка, 1976, 270 c.].

Chrtek J., Krisa B. A taxonomical study of the species Luzula spicata (L.) DC. sensu lato in Europe. Bot. Not., 1962, 115: 293-310.

Chrtek J., Křisa B. Luzula. In: Flora Europaea. Cambridge: Cambridge Univ. Press, 1980, vol. 5, pp. 111-116.

Dahl E. The phytogeography of Northern Europe: British Isles, Fennoscandia, and adjacent areas. Cambridge: Cambridge Univ. Press, 1998, 297 pp.

Deyl M. Plants, soil and climate of Pop Ivan. Synecological study from Carpathian Ukraine. Opera Bot. Čechica, 1940, 2: 1-290.

Ellenberg H., Weber H.E., Düll R., Wirth V., Werner W., Paulissen D. Zeigerwerte von Pflanzen in Mitteleuropa. 2 Auf. Scripta Geobot., 1992, 18: 1-258.

Free M., Robock A. Global warming in the context of the Little Ice Age. J. Geophys. Res., 1999, 104: 19,05719,070. doi: 10.1029/1999JD900233.

Frei E., Bodin J., Walther G.R. Plant species' range shifts in mountainous areas - all uphill from here? Bot. Helv., 2010, 120(2): 117-128. doi:10.1007/s00035-010-0076-y.

Grintescu I. Fam. Juncaceae. In: Flora Reipublicae Socialisticae România. Bucureşti: Edit. Acad. Reipubl. Soc. România, 1966, vol. 11, pp. 527-604.

Grulich V. Red List of vascular plants of the Czech Republic. $3^{\text {rd }}$ edition. Preslia, 2012, 84: 631-645.

Kirschner J. Juncaceae 1: Rostkovia to Luzula. In: Species Plantarum: flora of the World. Canberra: Australian Biol. Resources Study, 2002, part 6, 237 pp.

Kobiv Y. Response of rare alpine plant species to climate change in the Ukrainian Carpathians. Folia Geobot., 2017, 52(2): 217-226. doi: 10.1007/s12224-016-9270-z.

Kobiv Y., Prokopiv A., Nachychko V., Borsukevych L., Helesh M. Distribution and population status of rare plant species in the Marmarosh Mountains (Ukrainian Carpathians). Ukr. Bot. J., 2017, 74(2): 163-176. doi: 10.15407/ukrbotj74.02.163.

Krechetovych V.I., Barbarych A.I. Rodyna Sytnykovi (Juncaceae). In: Flora URSR. Kyiv: Vyd-vo AN URSR, 1950, vol. 3, pp. 21-61. [Кречетович B.I., Барбарич А.І. Родина Ситникові (Juncaceae). В кн.: Флора УРСР. Київ: Вид-во АН УРСР, 1950, т. 3, с. 21-61].

Kyyak V.H. Mali populyatsii ridkisnykh vydiv roslyn vysokohirya Ukrainskykh Karpat. Lviv: Liga-Press, 2013, 248 рр. [Кияк В.Г. Малі популяції рідкісних видів рослин високогір'я Украӥнських Карпат. Львів: Ліга-Прес, 2013, 248 c.].
Landolt E. Ökologische Zeigerwerte zur Schweizer Flora. Veröffentlichungen Geobot. Institut. ETH, 1977, 64: 1-208.

Matuszkiewicz W. Przewodnik do oznaczania zbiorowisk roślinnych Polski. Warszawa: Wyd-wo Nauk. PWN, 2002, 537 pp.

Mirek Z. Zasięgi wysokościowe roślin naczyniowych w Karpatach i ich klasyfikacja. Wiadom. Bot., 1989, 33: 57-64.

Moravec J. Rostlinná společenstva České republiky a jejich ohrožení. $2^{\text {nd }}$ ed. Severočeskou Přírodou. Suppl., 1995: $1-206$.

Olshanskyi I. Two Juncaceae species, that disappeared from Ukrainian Carpathians. In: $7^{\text {th }}$ Planta Europa Conference book of abstracts. Kolympary: Orthodox Acad. Crete, 2014, p. 35.

Pauli H., Gottfried M., Reiter K., Klettner C., Grabherr G. Signals of range expansions and contractions of vascular plants in the high Alps: observations (19942004) at the GLORIA master site Schrankogel, Tyrol, Austria. Global Change Biology, 2007, 13: 147-156. doi:10.1111/j.1365-2486.2006.01282.x.

Pawłowski B., Walas J. Les associations des plantes vasculaires des Monts de Czywczyn. Bull. Acad. Pol. Sci. Lett. B, 1949, 1: 117-181.

Rehman A. Materiały do flory Wschodnich Karpat zebrane w r. 1871 i 1872. Spraw. Kom. Fizjogr., 1873, 7: 1-39.

Spinoni J., Szalai S., Szentimrey T., Lakatos M., Bihari Z., Nagy A., Németh Á., Kovács T., Mihic D., Dacic M., Petrovic P., Kržič A., Hiebl J., Auer I., Milkovic J., Štepánek P., Zahradnícek P., Kilar P., Limanowka D., Robert R., Cheval S., Birsan M.-V., Dumitrescu A., Deak G., Matei M., Antolovic I., Nejedlí P., Štastný P., Kajaba P., Bochnícek O., Galo D., Mikulová K., Nabyvanets Y., Skrynyk O., Krakovska S., Gnatiuk N., Tolasz R., Antofie T., Vogt J. Climate of the Carpathian Region in the period 1961-2010: climatologies and trends of 10 variables. Int. J. Climatol., 2015, 35: 13221341. doi: 10.1002/joc.

Tkachyk V.P. Flora Prykarpattya. Lviv: NTSh, 2000, 254 pр. [Ткачик В.П. Флора Прикарпаття. Львів: НТШ, 2000, 254 c.].

Vyznachnyk roslyn Ukrainskych Karpat. Ed. V.I. Chopyk. Kyiv: Naukova Dumka, 1977, 433 pp. [Визначник рослин Українських Карпат. Ред. В.І. Чопик. Київ: Наук. думка, 1977, 433 с.].

Wołoszczak E. Drugi przyczynek do flory Pokucia. Spraw. Kom. Fizjogr., 1888, 22: 184-220.

Zapałowicz H. Roślinna szata Gór Pokucko-Marmaroskich. Spraw. Komis. Fizjogr., 1889, 24: 1-390.

Zarzycki K., Trzcińska-Tacik H., Różański W., Szelagg Z., Wołek J., Korzeniak U. Ecological indicator values of vascular plants of Poland. Kraków: W. Szafer Inst. Bot., Polish Acad. Sci., 2002, 183 pp.

Recommended for publication by

Submitted 10.11.2017 
Кобів Ю. Luzula spicata (Juncaceae) в Українських Карпатах: на межі зникнення. Укр. бот. журн., 2018, 75(1): 70-76.

Інститут екології Карпат НАН України вул. Козельницька, 4, Львів 790026, Україна

Ботанічний сад Львівского національного університету ім. Івана Франка

вул. Черемшини, 44, Львів 79014, Україна

Проаналізовано наявні історичні дані про поширення Luzula spicata в Українських Карпатах, наведені в публікаціях і гербарних зразках. Цей аркто-альпійський вид раніше траплявся на найбільших висотах у трьох гірських масивах: Чорногорі, Мармароських i Чивчинських горах. Він був приурочений до пісковикових чи конгломератових скель 3 кислою реакцією, розташованих на гірських вершинах чи хребтах, де температурний режим $€$ найнижчим. Недавнє ретельне обстеження усіх восьми раніше задокументованих локалітетів дозволило підтвердити наявність $L$. spicata лише в одному оселищі, а саме біля вершини г. Піп Іван у Чорногорі (1990 м н.р.м.), де збереглася його мала популяція. Очевидно, вид зник на решті території Українських Карпат. Подається карта теперішнього і зниклих локалітетів, а також ілюстрація недавно зібраного гербарного зразка. Luzula spicata один 3 найбільш кріофільних видів карпатської флори, а його локалітети в Україні приурочені до нижньої межі висотної амплітуди виду. Тому його регресування й вимирання пов'язані з кліматичними змінами, що було відзначено й в інших гірських системах Європи. Аналіз давніх даних свідчить, що цей вид найімовірніше зазнавав поступового відмирання ще з часу закінчення так званого малого льодовикового періоду (100-150 років тому), після якого розвивалося потепління. Luzula spicata - це низькоконкурентний вид, приурочений до наскельних оселищ 3 нещільною рослинністю. Він вразливий як до безпосереднього впливу потепління, так і до витіснення конкурентоспроможнішими злаковоосоковими чи чагарничковими видами, що проникають до альпійських оселищ у процесі кліматогенної сукцесії. Оскільки L. spicata перебуває на межі зникнення, ii слід внести до наступного видання "Червоної книги України" як критично загрожений (CR) вид.

Ключові слова: кріофільний вид, кліматичні зміни, локалітет, зникнення, Карпати
Кобив Ю. Luzula spicata (Juncaceae) в Украинских

Карпатах: на грани исчезновения. Укр. бот. журн., 2018 , 75(1): 70-76.

Институт экологии Карпат НАН Украины ул. Козельницкая, 4, Львов 79026, Украина

Ботанический сад Львовского национального университета им. Ивана Франко ул. Черемшины, 44, Львов 79014, Украина

Проанализированы имеющиеся исторические данные о распространении Luzula spicata в Украинских Карпатах, приведенные в публикациях и гербарных образцах. Этот аркто-альпийский вид раньше встречался на наибольших высотах в трех горных массивах: Черногоре, Мармарошских и Чивчинских горах. Он приурочен к песчаниковым или конгломератовым скалам с кислой реакцией, расположенным на горных вершинах или хребтах с самым низким температурным режимом. Недавнее тщательное обследование всех восьми ранее задокументированных локалитетов позволило подтвердить наличие $L$. spicata только в одном местопроизрастании, а именно возле вершины г. Поп Иван в Черногоре (1990 м н.у.м.), где сохранилась лишь малая популяция. Очевидно, вид исчез на остальной территории Украинских Карпат. Прилагается карта сохранившегося и исчезнувших локалитетов, а также иллюстрация недавно собранного гербарного образца. Luzula spicata - один из наиболее криофильных видов карпатской флоры, а его локалитеты в Украине приурочены к нижней границе высотной амплитуды вида. Поэтому его регрессирование и вымирание связаны с климатическими изменениями, что отмечалось и в других горнах системах Европы. Анализ давних данных свидетельствует, что этот вид вероятно подвергался постепенному вымиранию еше со времени окончания так называемого малого ледникового периода (100-150 лет назад), после которого развивалось потепление. Luzula spicata - низкоконкурентный вид, приуроченный к наскальным местообитаниям с разреженной растительностью. Он уязвим как к непосредственному воздействию потепления, так и к вытеснению более конкурентоспособными злаково-осоковыми или кустарничковыми видами, проникающими в альпийские местообитания в ходе климатогенной сукцессии. Поскольку L. spicata пребывает на грани вымирания, ее следует включить в следующее издание "Красной книги Украины" как находящийся под критической угрозой исчезновения (CR) вид.

Ключевые слова: криофильный вид, климатические изменения, локалитет, исчезновение, Карпаты 